\title{
An applicable model for Free Industrial-Economic Zone(FIEZ) in Navoi in cooperation with Korea
}

\author{
Bakhodyr Khodjaev* and Se Kwang $\mathrm{Oh}^{* *}$
}

\begin{abstract}
Advantage of its geologic location lying at the heart of Central Asia with a large internal market of 27 million people and easy access to CIS market of over 142 million people enables Uzbekistan to form the hub of the region. Its transport and communications networks are connected with the other Central Asian countries. FIEZ in Navoi would be the representative model in CIS and be built on the best practice of next generation model as special national economic zones. Considering that the most of modern business is made through the web connection basis even for the flight management, cargo trace and other controls and operations, the importance of web connection should be stable, reliable and affordable for tenants and business entities at the FIEZ in Navoi. In these regards, cooperation work of both countries to study more details mentioned in this paper as well as other applicable models from Korean Free Economic Zone cases for the full picture of execution and promotion of the FIEZ in Navoi, Uzbekistan is considered.
\end{abstract}

Keywords: navoi, FIEZ, ICT, collaboration model

Submission Date: 4/14/2010 Revision Date: 10/31/2010

Acceptance Date: 11/10/2010

* Corresponding Author, Vice-rector of University of World Economy and Diplomacy in Uzbekistan, email : bkhodjaev@uwed.uz

** Head of Representative Office, Korea Telecom 


\section{Introduction}

Since the Republic of Uzbekistan (hereinafter Uzbekistan) established diplomatic relations with the Republic of Korea (hereinafter Korea) for its first strategic economic cooperation partner on 29 January 1992 right after its independence on 30 December 1991, both countries kept close ties through mutual collaboration in various fields with nine high level meetings between the leaders of both republics.

Recently, on 11 February 2010, the presidents of both countries, Islam Karimov and Lee Myung-Bak met in Seoul during the state visit of the President of Uzbekistan to Korea.

At the face-to-face talks, the two leaders considered the present state and perspectives of relations between Uzbekistan and South Korea, as well as regional and international issues.

The economic cooperation between Uzbekistan and South Korea is developing rapidly. The states are implementing large projects in oil and gas, mining, automobile manufacturing, logistics, textile and chemical industries, construction, ICT and other sectors.

The negotiations of the presidents continued with the participation of the official delegations of the two countries. The main focus of the talks was trade, economic, investment and humanitarian cooperation .

After the negotiations in Seoul, the sides signed a total of 16 documents, covering cooperation in areas like infrastructure, medicine, environmental protection, tourism, agriculture, etc. Among them are the Agreement on cooperation in development of alternative energy sources and power saving technologies and the Investment agreement on the construction of Ustyurt gas and chemical complex at Surgil deposit (north Uzbekistan).

In addition, the humanitarian cooperation between the two countries has also been expanding. In 1992, a Korean Education Center was opened in Tashkent. Uzbek State World Languages University and Samarkand State Foreign Languages Institute have centers for Korean language and culture, while Tashkent IT University has an IT center created with support of South Korea.

The Uzbekistan-Korea professional training center was another achievement in the educational cooperation. Annually, 360 young people are taught here in fields like PC assembly, agricultural machinery repair, car service and more.

Now, as one of the Knowledge Sharing Programs (KSP) of Korea for Asia, Korean veteran economic policymakers will be dispatched to Uzbekistan to work as advisors to the governments of Uzbekistan over the next three years.

The KSP may help Uzbekistan develop its economic potential using Korea's experience in managing macro-economy, promoting innovations, exports and investments for rapid economic growth over the past five decades. At the same time, the plan will effectively boost the morale of citizens and officials in Korea.

As the grant-aid projects of Korea, the following four fields are being arranged for Uzbekistan. 
- Improvement of medical care for patients with infectious diseases

- Improvement of the heat supply system

- Improvement of the drinking water supply

- Development of techniques for salt reduction of collector-drainage water for reuse.

\subsection{Korean Investment in Uzbekistan}

Actually, Uzbekistan is ranked 150th out of 183 for 'ease of doing business' according to the World Bank's statistics.

But, thanks to the recent efforts of the government backed by the private sector and business associations, the business environment is being improved. The Uzbek Chamber of Commerce and Industry holds business forums and regularly communicates with the government about changes that need to be made. It has won the right to participate in the formulation of all laws affecting entrepreneurship. For example, the government, reacting to suggestions, has streamlined the business registration process into a "single window". It has also drafted a new tax code which is simple and less burdensome. Moreover, growing public-private sector dialogue is helping the Government move in the right direction.

The figure shows that these kinds of efforts are working properly. For example, foreign investments to Uzbekistan are increasing gradually, from 172.4 billion UZS in 2000 to 2,193.7 billion UZS in 2008. In addition, foreign trade turnover reached 14,227.1 million USD in 2008 from 6,212.1 in 2000 with the balance of exports-imports by 3,755.9 million USD.

In accordance with the Trade Agreement of 1992, the most favored nation treatment was achieved. Korea occupies a leading position among trade partners of Uzbekistan in the Asia-Pacific region. According to the State Statistics Committee of Uzbekistan, in the third quarter of 2009 the trade turnover increased by $7 \%$ and accounted for $\$ 847$ million (exports of Uzbekistan - \$71.4 million, imports - \$775.6 million).

In the last few years Korean companies have been actively participating in various projects in the territory of Uzbekistan, including the implementation of oil and gas fields, the construction of gas-chemical complexes, and the construction of residential and commercial complexes. in the privatization processes be means of acquiring assets of enterprises; in the establishment of joint ventures in textile and other fields of economy.

Korea is one of the largest investment partners of Uzbekistan and its investment cooperation is expanding. To date, the volume of Korean investments into Uzbekistan's economy has exceeded $\$ 2$ billion. With implementation of the arrangements secured during the visit of the Uzbek President to Seoul this year such indicators will make up \$5 billion.

In addition, the Korean government plans to continually increase EDCF and ODA support quantitatively and qualitatively.

Classified as an EDCF priority country, Uzbekistan is an important partner country for economic cooperation. To date, approximately $\$ 117$ million has been provided for five projects in Uzbekistan aimed at developing telecommunications, human resources development, and 
public health and healthcare, making it the tenth largest EDCF beneficiary country globally and the single largest beneficiary in the CIS. EDCF projects will undoubtedly serve to advance mutually beneficial economic cooperation even further between the two countries.

\subsection{FIEZ (Free Industrial-Economic Zone)}

President Islam Karimov signed a decree on the creation of a FIEZ in the Navoi region in December 2008 to increase the industrial potential, the developmen of transport and social infrastructure, the production of high technologies, and the attraction of foreign investments to the region. Benefits of registering businesses in the FIEZ will last for 30 years with the opportunity for further extension.

During the term of the functioning of the FIEZ, special customs, foreign currency and tax regime, a simplified procedure for entering, staying and leaving, as well as receiving a license to carry out labour by non-residents of Uzbekistan will be in force in its territory. It is considered that to do businesses here has the advantage of penetrating other markets with a location near an international highway, which is the shortest connection between Europe and East Asia, and a railroad with access to the markets of Central Asia, the Commonwealth of Independent States (CIS), Southeast Asia, Europe, the Middle East and Persian Gulf countries as well as International Airport.

About USD \$ 65 million was allocated to projects in the zone for construction of a road from the international highway to Navoi Airport, the railway road, the gas pipeline, the water system and other infrastructures .

Currently, there are 40 agreements with foreign partners on the realization of projects in Navoi. The number of projects, realized at the FIEZ is expected to reach 100 in 2010 and investment volume can make up USD $\$ 5$ billion, according to assessments.

The realization of creating the FIEZ in Navoi is being actively conducted with the participation of Korean companies. One of the main steps in promoting the project is establishing an international logistics center on the basis of Navoi airport and it is already in operation as of the end of March, 2010.

In addition, last December, Korean Air launched construction of three residential blocks consisting of 90 houses with a total area of 17,200 square meters at the FIEZ in Navoi. The complex, to open by August 2010, will include a recreation park and other objects. Korean Air has been operating new cargo and passenger transportation routes via Navoi international airport since August 2008.

\section{ICT (Information and Communication Technologies)}

Up-to-date information and communication technologies facilitating many spheres of human activity are getting introduced more and more intensively into our lives. A nation's 
ICT level has become a mainstream of industry growth and has gradually become an important determiner of its competitive power. As described in the table below, Korea has one of the highest ICT levels in the world. Uzbekistan has strong potential to increase its ICT level in the near future.

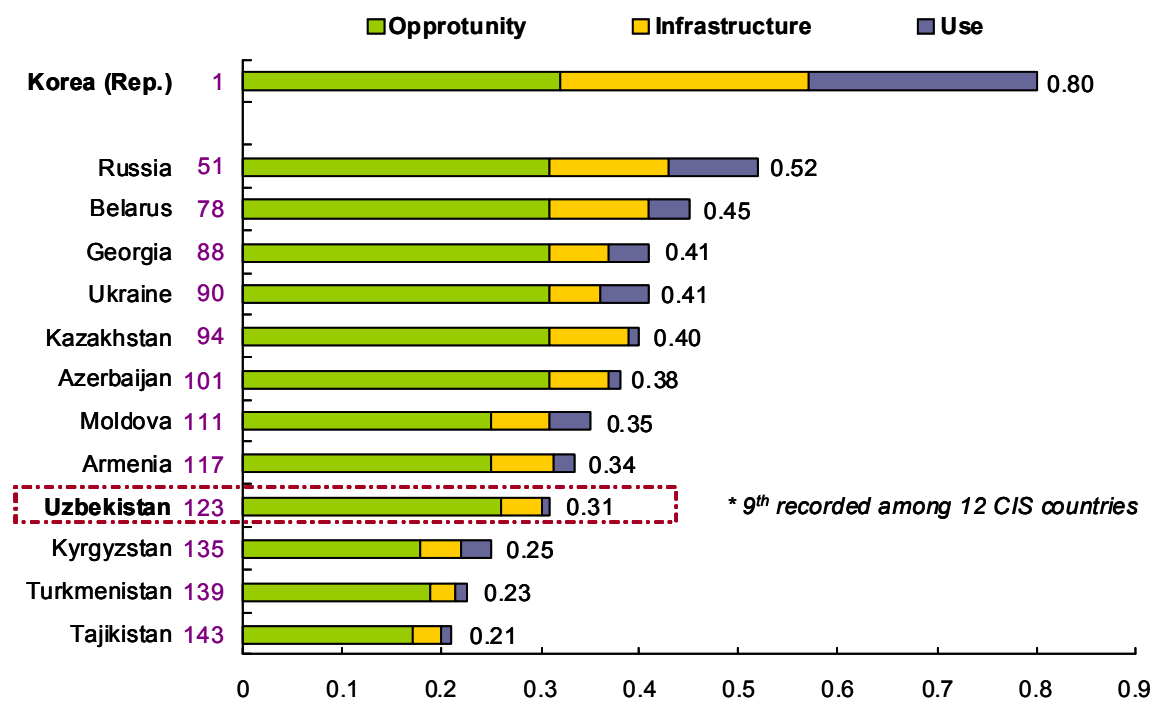

Source: ITU, Digital Opportunity Index 2005/06

Figure 1.

Nation's ICT Level

Uzbekistan still has very limited access to ICTs, especially in terms of broadband infrastructure and household access and the gap between the high and low groups is still significant although it is shrinking slightly. In this regard, it is necessary for Uzbekistan to invest in ICT for strengthening national competitive power over other CIS countries.

Anyway, in terms of infrastructure development, the telecommunications sector has seen the most rapid development. The telecommunication sector is of critical importance both for communications and for the transfer of information. The volume of information transferred worldwide is doubling every two to three years. The more rapidly Uzbekistan upgrades its telecommunications sector, the more completely it will integrate into the global economy and put an end to the isolation it has endured since the demise of the Silk Road.

The creation of a modern telecommunications infrastructure is considered one of the most important factors increasing business activity and transferring knowledge. Uzbekistan has been implementing concepts of e-trade and e-government as a result of rapid growth in the telecommunications sector. 
Demand for services such as mobile telephones and broadband Internet have remained buoyant despite the economic crisis and the trend is currently undergoing a generational shift from fixed telephone networks to mobile connections of all types, next generation networking and broadband wireless networks. Previously clear borders among telephones, broadcasting and online services are being eroded, with people able to watch movies on their computers and programming being downloaded on mobile phones.

As a result, ICT regulators may play a key role in fostering ongoing innovation and competition, enabling operators to adopt the latest, most powerful technologies, and ensuring consumers enjoy the very best range of services at the lowest possible prices.

So, it is recommended to study how ICT can help stimulate investment and conduct successful creations of special economic zones in Samarkand, Navoi and Bukhara as well as the FIEZ in Navoi.

\section{The FIEZ in Navoi with ICT}

The President of Uzbekistan, Islam Karimov, signed a resolution on 27 January on the State Program "Year of harmoniously developed generation" for proclaiming 2010 as the Year of the harmoniously developed generation in Uzbekistan.

The document envisages implementation of a wide range of measures aimed at the creation of required conditions in the country for bringing up a healthy and harmoniously developed generation, and realization of the young people's potential. Among the key tasks of the program are improvement of legislation related to protection of the rights and interests of the children and youth, and expanding reforms in the healthcare sector.

The program also stipulates improvement of educational standards, study programs and literature, improvement of education in schools, professional colleges and lyceums, wide introduction of ICT in education and stimulating teachers .

One of the tasks included in the State Program is the development and introduction in the people's lives the modern information and communication technologies, digital communication tools and the Internet.

In this regard, the following chapter may show one of the ways that both countries cooperate to enhance the circumstances of ICT in Uzbekistan.

\subsection{Production of national low-price computers}

To boost the actual internet use of the Uzbek people, supplying personal computers and/or terminals connectable to the Internet is essential. But, considering the ordinary income of averagel household in Uzbekistan, especially in the provinces, it is economically difficult to realize.

Providing economic PCs and internet connections to every household in Uzbekistan 
with support from the Korean EDCF (Economic Development Cooperation Fund) is an option being considered.

With the goal of supplying PCs and internet connections to 500,000 households in Uzbekistan by the year of 2020, the target can be initiated by the Korean EDCF, for the about USD \$ 40 Mil. for 100,000 households by 2011 .

In addition, every 100,000 households would be kept of expansion with the amortization of existing subscribers and local bank loans through local telecommunication companies for every other year until most of the people in Uzbekistan are able to enjoy web surfing without any economic hindrance.

The economic PCs, having general specifications to meet the requirements of normal internet users, would be supplied to each household. These PCs could be manufactured at the FIEZ in Navoi by Korean companies and/or imported from Korea at prices ranging from US\$ 300 to US\$ 400. A 2-3 year payment plan, with monthly installments between \$30-40 USD could be implemented including internet connection charges with unlimited use of intranet in Uzbekistan

There are many things we can expect not only for promotion of the FIEZ in Navoi, but also for the following effects.

Firstly, to boost the actual use of PCs and the Internet all over the country

- Release economic burden on PC purchase and Internet use

- Learn more about PC applications and easy access to e-educational contents

- Activate Internet usage of people for national e-government as well as on-line services, on-line markets and etc.

- Cultivate Uzbek students as future world leaders having the profound knowledge of the world through e-contents

Secondly, to lead remarkable growth of the software industry as well as on-line games, on-line markets and various content development industries.

- Development and growth of related industries like on-line security, on-line payment and etc.

- Realization of e-learning environment

- Development and integration of e-education contents and databases of all related educational entities

\subsection{International Internet Channel Expansion}

Expansion of international telecommunication channels including internet capacity and secure redundancy channels for emergency through satellite connections to Korean stable and sufficient international links may need to be considered for better ICT circumstances in Uzbekistan. 


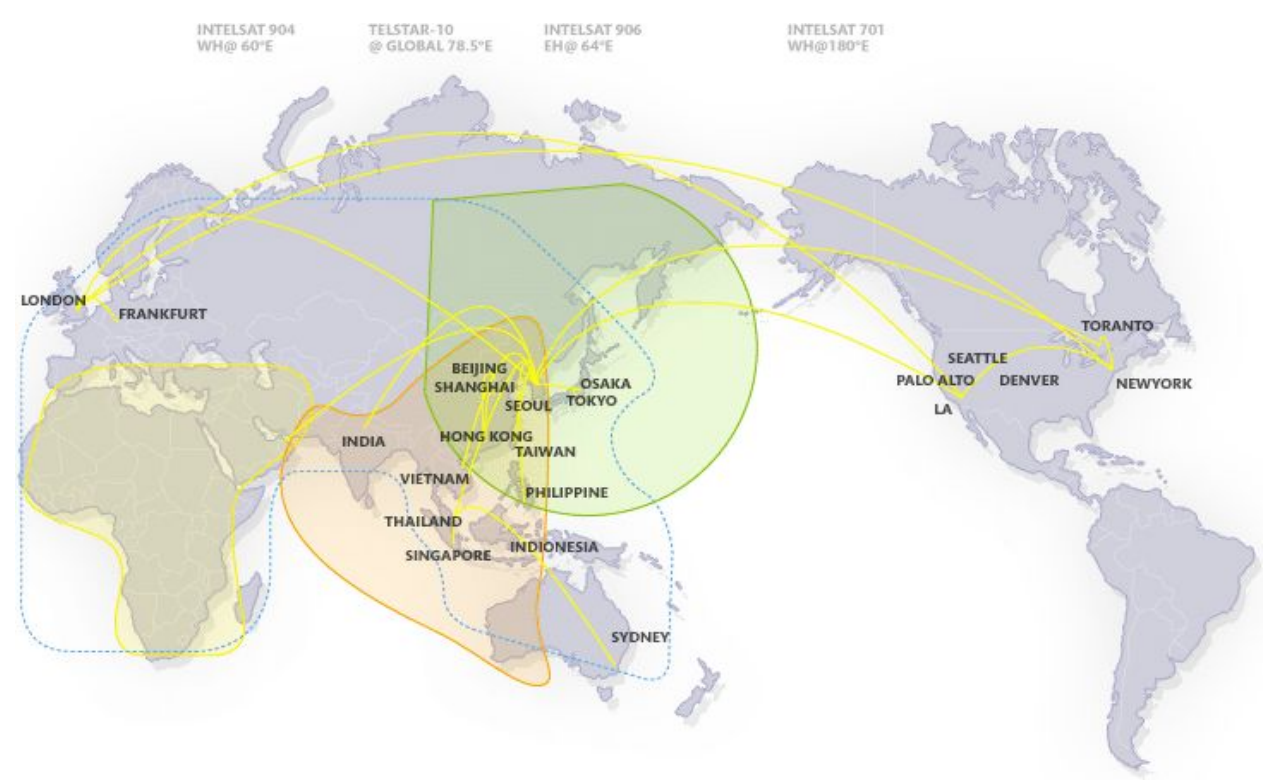

Figure 2.

Worldwide Network Connections via Satellite

Having only terrestrial links to international networks and sole ISPs (Internet Service Providers) isolates Uzbekistan uring nationa 1 disasters and/or malfunctions of the operator. In this regard, national telecommunication redundancy channels should be considered and secured.

In addition, higher costs and limited international link capacity may restrict the expansion of internet usage of the public. To become an advanced information/knowledge-based society, worldwide high-speed Internet connections at lower costs are necessary.

Finally, various routes for global telecommunication networks are essential for stable and reliable connections to high-speed Internet. world This would encourage international companies to invest in or launch their business or capital in Uzbekistan with confidenc.

So, building the earth station with related infrastructure at the FIEZ in Navoi and providing high-speed internet and voice/data services at lower prices and higher rates of reliability directly connected to Korea will meet the demands of tenants at the FIEZ in Navoi as well as most international companies having business relations with the FIEZ in Navoi in advanced IT environments in a convenient and safe manner.

After its successful operation at the FIEZ in Navoi, its capacity and coverage to main cities and provinces in Uzbekistan can be expanded for independent redundant telecommunication channels against national disaster and for business efficiency/effectiveness enhancement and guarantee of security along with Korean efficient management/operation support. With this, it would be expected as benefits of Uzbekistan as follows; 
- IT Hub in CIS region with better IT environments for Internet users, all industries and governmental agencies with the identity of a high IT tech country

- Create huge demands through integrating various information infrastructures, technologies and services

- Network monitoring and management over worldwide connections can be available through an integrated network operation and control center.

- Technical/Engineering know-how for network operation of Korea would be transferred to Uzbekistan

\section{Summary}

The advantage of its geologic location, lying at the heart of Central Asia, with a large internal market of 27 million people and easy access to CIS market of over 142 million people enables Uzbekistan to become the hub of the region. Its transport and communications networks are connected with the other Central Asian countries.

In addition, the labor force of Uzbekistan possesses a number of important characteristics; it is ample, literate (almost 100 percent literacy), young and highly trainable. The younger labor force entrants are often fluent in foreign languages and have acquired basic business skills. And this pool of skilled workers is available to investors at a low cost.

Uzbekistan is also consistently trying to reform its economy and create a friendly business environment to attract and retain foreign direct investments.

All these efforts work simultaneously and could be the basis of the success of the country in investment promotion.

The FIEZ in Navoi would be the representative model in CIS and be built on the best practices of next generation model as special national economic zones.

There are many incentives and benefits provided to enterprises and investors participating in the FIEZ investment program. In addition, basic infrastructure for tenants of the FIEZ in Navoi will be fully provided, such as transportation (highways, railroads, airports, logistics and etc.), electric power, gas, water, international telecommunication links, and etc.

Considering that the most modern business is made through the web connection basis even for the flight management, cargo trace and other controls and operations, the importance of web connections should be stable, reliable and affordable for tenants and business entities at the FIEZ in Navoi.

In addition, all employees of the territory should be familiar with the use of PCs and Internet to build electronic and/or automatics facilities and process systems as well as office work.

In these regards, cooperation work of both countries to study more details on the proposals mentioned in chapter 3 as well as other applicable models from Korean Free Economic Zone cases for the full picture of execution and promotion of the FIEZ in Navoi, Uzbekistan is necessary. 
